\title{
Effect of Seed Oil and Methanol Leaf Extract of Dialium guineense Steud on Wound and Inflammation
}

\author{
Adediwura A FRED-JAIYESIMI ${ }^{*}$, Peter A SEGUN ${ }^{1}$, Modupe N ADEBOWALE 1 , Oluwakemi \\ OGUNLEYE ${ }^{1}$, Mary ADESINA ${ }^{1}$, Katherine OLUFOLABO $0{ }^{1}$ \\ 1Department of Pharmacognosy, Faculty of Pharmacy, Olabisi Onabanjo University, Sagamu Campus. Ogun State, \\ Nigeria.
}

\begin{abstract}
Dialium guineense native to the Sub-Saharan Africa serves as a good source of vitamins particularly Vitamin $\mathrm{C}$ for children, it is used in folklore medicine as treatment for cough, fever, stomachache, ulcer, wounds and in improving lactation in women. This study aims at investigating the anti-inflammatory and wound healing effects of the crude methanol extract, seed oil, ointments of the extract and seed oil. The phytochemical analysis of the leaf and seed of Dialium guineense were assayed for secondary metabolites. The egg-albumin method was adopted for the anti-inflammatory study while the excision wound model was used to determine the wound healing effect in rats. The presence of Anthraquinones, flavonoids, saponins and sterols were present in the leaf and seed of Dialium guineense. The leaf extract and seed oil of Dialium guineense exhibited anti-inflammatory effect which were not significantly different at the various doses tested ( $200 \mathrm{mg} / \mathrm{kg}, 100 \mathrm{mg} / \mathrm{kg}, 50 \mathrm{mg} / \mathrm{kg}$ ). The ointment of the leaf extract as well as the seed oil exerted pronounced wound healing effect of $77.8 \%$ and $85.7 \%$ wound contraction respectively on day 19 .The seed oil of Dialium guineense showed a faster wound healing effect than the leaf by creating occlusive effect on the wounds against moisture. Furthermore, the presence of phenolic compounds in the leaf and seed oil exerted a synergistic anti-inflammatory and wound healing effect.
\end{abstract}

Keywords: Dialium guineense, wound healing, anti-inflammatory, seed oil, leaf.

\author{
Corresponding Author*: \\ Fred-Jaiyesimi Adediwura A \\ aa.fred-jaiyesimi@oouagoiwoye.edu.ng \\ $+2348022898155$ \\ ORCIDs \\ Adediwura A. Fred-Jaiyesimi ORCID number 0000-0002-5906-9155 \\ Peter A. Segun ORCID number 0000-0002-2177-4609 \\ Modupe N. Adebowale ORCID number 0000-0002-0944-0702 \\ Oluwakemi Ogunleye ORCID number 0000-0002-1575-9605 \\ Mary Adesina ORCID number 0000-0003-3054-9339 \\ Katherine 0. Olufolabo ORCID number 0000-0003-3054-9339
}




\section{INTRODUCTION}

Dialium species of the family Fabaceae are common to the Sub-Saharan Africa, with about twenty-four species, five of these species are indigenous to the West African countries ${ }^{1}$ of which Dialium guineense is one of them, it is commonly known as the velvet tamarind, black velvet or tumble tree, Awin (Yoruba), Icheku (Igbo), Tsamiyar Kurmi (Hausa) ${ }^{2,3}$ It grows to a height of about $30 \mathrm{~m}$ and $0.8 \mathrm{~m}$ in diameter ${ }^{4}$.

In Nigeria, the fruits of D. guineense are abundant between the months of January and May ${ }^{5}$ These edible fruits are good source of protein, minerals, and Vitamin $\mathrm{C}^{6 .}$

In traditional medicine, various parts of D. guineense are used for treating diseases such as cough, fever, stomachache. The fruits are taken to improve lactation in women ${ }^{2}$, treat malaria, jaundice, stomachache, ulcer, malnutrition, as well as in treating wounds, hemorrhoid ${ }^{7}$ and in the prevention of cancer.

Several studies have reported the biological activities such as antidiarrhoeal , antimicrobial ${ }^{8}$, antiulcerogenic , antibacterial ${ }^{3,9,10,11}$ and anticancer activities ${ }^{12}$ of $D$. guineense. In addition, some secondary metabolites have been identified in the leaf and stembark of D. guineense, these include tannins, alkaloids, flavonoids, saponins, sterolds and cardiac glycosides ${ }^{13,14,15}$.

This study aims at investigating the anti-inflammatory and wound healing activities of the methanol leaf extract and seed oil of Dialium guineense.

\section{METHODOLOGY}

\section{Materials}

The leaf and seed of Dialium guineense were collected from growing tree in Ibadan and Sagamu, Oyo and Ogun States, respectively. The plant was authenticated at the Herbarium Department of the Forestry Research Institute of Nigeria (FRIN), Ibadan, Nigeria where a voucher specimen was deposited.

\section{Drying}

The leaves were dried under shade while the seeds were removed from the pulp and air dried. The dried leaves and seeds were milled to powder and stored in containers for further use.

\section{Extraction}

300 of powdered leaf sample was extracted by cold maceration in $70 \%$ methanol for $72 \mathrm{hrs}$ while $300 \mathrm{~g}$ of the powdered seeds were macerated in Hexane for $72 \mathrm{hrs}$. These were filtered separately, and the filtrates concentrated to dryness under reduced pressure in a Rotary evaporator. 


\section{Phytochemical Screening}

The powdered leaf and seed of $D$. guineense were analysed for secondary metabolites ${ }^{16,17}$.

\section{Anti-inflammatory Activity}

The anti-inflammatory activity of the leaf extract and seed oil were carried out in wistar rats using the egg albumin model ${ }^{18}$. Healthy Wister rats obtained from the Animal House of Babcock University Ilishan, Ogun State, Nigeria were used for the study. They were allowed to acclimatize and had access to water ad libitum and rats' pellets. The weights of the Wistar rats ranged from $160 \mathrm{~g}$ to $200 \mathrm{~g}$.

The hind right paws of the animals were induced with $0.2 \mathrm{~mL}$ of fresh hen egg albumin and the diameter of the paws were taken and recorded as values for 0 $\min \left(\mathrm{T}_{\mathrm{o}}\right)$.

Table 1: Animal Grouping

\begin{tabular}{|l|l|}
\hline Group A & Rats received $200 \mathrm{mg} / \mathrm{kg}$ of the methanol leaf extract \\
\hline Group B & Rats received $100 \mathrm{mg} / \mathrm{kg}$ of the methanol leaf extract \\
\hline Group C & Rats received $50 \mathrm{mg} / \mathrm{kg}$ of the methanol leaf extract \\
\hline Group D & Rats received I $\mathrm{mL}$ of seed oil \\
\hline Group E & Rats received $0.5 \mathrm{~mL}$ of seed oil \\
\hline Group F & Rats received $0.25 \mathrm{~mL}$ of seed oil \\
\hline Group G & Rats received $5 \mathrm{mg} / \mathrm{kg}$ of Diclofenac sodium (Reference drug) \\
\hline Group H & Rats received I $\mathrm{mL}$ of water only (Untreated Group). \\
\hline
\end{tabular}

Thirty minutes after administering extract, seed oil, Diclofenac and water to respective groups, orally, $0.2 \mathrm{~mL}$ of fresh egg albumin was injected into the right hind paw of each rats in the different groups. The linear circumference of the injected paws was measured and recorded immediately after injecting with egg albumin (o hr); the diameter of the paw was then taken at an interval of 30 minutes for five hours.

The percentage inhibition of oedema was measured using the following formula \% Inhibition of oedema = Io $-\mathrm{I}_{1} \mathrm{X} 100$

Io

Io - Initial paw circumference

$\mathrm{I}_{1}$ - Change in paw circumference at time interval 


\section{Wound Healing}

The wound healing effect of the methanol leaf extract and seed oil of Dialium guineense was carried out by the Excision wound model ${ }^{19,20}$.

\section{Excision Wound Model}

The excision wound model was used to evaluate the wound healing activity of Dialium guineense leaf extract and seed oil. The wound excision was made through full thickness of the skin with sterile blade. The length and Circumference of the wounds were measured using a tracing paper on the wound and measuring the circumference with a meter ruler ${ }^{21}$. The length and circumference of the wound were taken on day 1, 3, 5, 9, 12, 15, 19.

The doses of the leaf extract and seed oil ointments were $2 \% \mathrm{w} / \mathrm{w}, 5 \% \mathrm{w} / \mathrm{w}, 10 \%$ $\mathrm{w} / \mathrm{w}$ and $100 \%$ seed oil. Povidone iodine was used as standard drug, and these were applied topically on the animal wounds every day for nineteen days.

\section{Simple Ointment}

Simple ointment based on the British Pharmacopoeia (BP) was prepared using white soft paraffin, wool fat, cetostearyl alcohol, Hard paraffin and the leaf extract and seed oil of $D$. guineense ${ }^{22,23}$.

\section{Statistical Analysis}

Data of the study are presented as Percentage, mean \pm Standard error of mean (SEM) of sample size $(\mathrm{n}=5)$. Mean values were compared statistically by oneway analysis of variance (ANOVA) followed by post hoc Turkey's test multiple comparison using Statistical package for Social Sciences (SPSS version 20). $\mathrm{P}<0.05$

\section{RESULTS and DISCUSSION}

The skin serves as a medium between the internal and external environment, any disruption of the anatomy of the epidermis by physical, biological, and thermal stimuli leads to wound ${ }^{24}$. Inflammation is one of the processes of wound healing by protection against tissue damage through the elimination of pathogens and cell debris ${ }^{25}$, however when the inflammation becomes severe, it leads to production of excess oxidative stress which acts as etiologic factor for chronic diseases $^{19}$

Wound healing occurs through diverse phases which involves hemostasis, inflammation, proliferation, and remodeling of tissues. During these processes of healing, a wound matrix is involved followed by a breakdown and cleanup of tissues and pathogen debris. 
The leaf extract ointment of D. guineense at 2\%, 5\% and 10\% all produced healing effect on the wounds of the animals with percentage contraction of $77.8 \%$, $60.8 \%$ and $66.1 \%$ respectively. Though there was no dose dependent effect observed, wound contractions became obvious from day 5 . In addition, the healing effect of the different doses of the ointments incorporated with the leaf extract were not significantly different from that exhibited by the standard drug which had $66.7 \%$ contraction. (Table 2).

Table 2: Percentage wound contraction of Dialium guineense leaf and seed oil

\begin{tabular}{|c|c|c|c|c|c|c|c|}
\hline \multicolumn{7}{|c|}{ Percentage wound contraction (\%) } \\
\hline $\begin{array}{c}\text { Group } \\
\text { (Treat- } \\
\text { ment) }\end{array}$ & Day 3 & Day 5 & Day 7 & Day 9 & Day 12 & Day 15 & Day 19 \\
\hline $\begin{array}{c}2 \% \text { leaf } \\
\text { extract }\end{array}$ & $9.3 \pm 6.8$ & $25.4 \pm 8.7$ & $33.2 \pm 5.3$ & $61.9 \pm 3.1$ & $69.9 \pm 4.3$ & $73.9 \pm 3.9$ & $77.8 \pm 3.4$ \\
\hline $\begin{array}{c}5 \% \text { leaf } \\
\text { extract }\end{array}$ & $15.0 \pm 4.9$ & $25.3 \pm 7.6$ & $35.6 \pm 7.6$ & $45.6 \pm 5.5$ & $54.6 \pm 3.4$ & $57.4 \pm 2.9$ & $60.8 \pm 3.0$ \\
\hline $\begin{array}{c}10 \% \text { leaf } \\
\text { extract }\end{array}$ & $5.9 \pm 2.9$ & $16.5 \pm 7.9$ & $28.8 \pm 5.0$ & $48.0 \pm 3.1$ & $55.5 \pm 2.0$ & $58.5 \pm 2.0$ & $66.1 \pm 2.4$ \\
\hline $\begin{array}{c}2 \% \text { oil } \\
\text { extract }\end{array}$ & $13.1 \pm 4.2$ & $20.8 \pm 2.6$ & $39.6 \pm 4.2$ & $57.3 \pm 2.1$ & $64.0 \pm 1.2$ & $69.6 \pm 2.2$ & $80.4 \pm 1.4$ \\
\hline $\begin{array}{c}5 \% \text { oil } \\
\text { extract }\end{array}$ & $9.6 \pm 3.9$ & $18.4 \pm 6.5$ & $29.0 \pm 2.3$ & $48.3 \pm 2.3$ & $58.6 \pm 1.5$ & $62.4 \pm 2.3$ & $70.7 \pm 0.5$ \\
\hline $\begin{array}{c}10 \% \text { oil } \\
\text { extract }\end{array}$ & $12.2 \pm 6.1$ & $\begin{array}{c}26.1 \\
\pm 12.1\end{array}$ & $\begin{array}{c}27.9 \\
\pm 11.9\end{array}$ & $59.6 \pm 8.5$ & $64.1 \pm 6.2$ & $67.5 \pm 5.4$ & $85.7 \pm 1.1$ \\
\hline \begin{tabular}{c}
$100 \%$ oil \\
\hline Standard \\
drug
\end{tabular} & $5.5 \pm 1.4$ & $18.8 \pm 3.8$ & $25.7 \pm 1.5$ & $46.9 \pm 5.3$ & $56.9 \pm 4.5$ & $60.8 \pm 5.1$ & $74.5 \pm 5.6$ \\
\hline
\end{tabular}

$\%$ wound contraction $=$ Day 1 wound circumference - Day n wound circumference X1oo

\section{Day 1 wound circumference}

The seed oil ointment at $2 \%$ and $10 \%$ exerted more pronounced healing effect of $80.4 \%$ and $85.7 \%$ contraction than those exhibited by the leaf extract $(77.8 \%$ and $66.1 \%$ contraction) on Day 19. Though the seed oil alone healed the wound by $74.5 \%$ contraction, the effect was not as prominent as those of the seed oil ointments of $2 \%$ and $10 \%$.

The ability of plant oils to act as a protective barrier to the skin when applied on the skin surface thereby making available the active ingredients present in the oil for the skin have been well documented. In addition, ointments incorporat- 
ed with plant oils are used in the treatment of wounds because of their ability to create an occlusive effect against moisture, hence the use of simple ointment incorporated with the leaf extract and seed oil of Dialium guineense in this study. Furthermore, the choice of use of ointment in this study is also because of the ability to sustain drug release at application site and as barrier for moisture ${ }^{23}$.

The presence of tannins, terpenoids and flavonoids have been previously reported to play vital roles in wound healing ${ }^{26,27}$ by affecting one or more phases of wound healing process ${ }^{28}$. The presence of these secondary metabolites in the leaf extract and seed of Dialium guineense are probably responsible for their ability to heal the wounds by increasing the wound contraction through the activation of fibroblasts, stimulation of collagen deposit, a process assisted by phenolic constituents such as those detected in the leaf and seed of D. guineense. These phenolic compounds also aid wound healing by collagen formation, wound closure, and epithelialization due to the anti-inflammatory, antibacterial and antioxidant properties which they possess ${ }^{24}$

The phytochemical analysis of Dialium guineense in this study revealed the presence of free and combined Anthraquinones, saponins, Tannins in high quantities, Alkaloids and sterols in moderate quantities, trace of flavonoids and absence of cardiac glycosides.

Table 3: Phytochemical Analysis of Leaf and Seed of Dialium guineense

\begin{tabular}{|c|c|c|c|c|c|c|c|c|c|}
\hline Morphological part & \multicolumn{2}{|c|}{ Anthraquinone } & Flavonoids & Saponins & Tannins & Alkaloids & Sterols & $\begin{array}{c}\text { Cardiac } \\
\text { glycosides }\end{array}$ \\
\hline & Free & Combined & \multicolumn{7}{|l|}{} \\
\hline Leaf & +++ & +++ & + & +++ & +++ & ++ & ++ & - \\
\hline Seed & + & + & + & ++ & - & - & + & + \\
\hline
\end{tabular}

+++ = Highly Present; ++ = moderately present; += Present; - = Absent.

In previous studies, the presence of tannins, alkaloids, flavonoids, saponins, steroids and cardiac glycosides in the leaf and stembark of D. guineense were reported ${ }^{13,14}$. Furthermore, the fruit coat extract has been shown to possess alkaloids and saponins in high concentration, flavonoids and steroids in trace quantities ${ }^{29}$ while, the presence of anthraquinone, alkaloids, flavonoids, tannins and saponins ${ }^{30}$ were moderately present.

The variations in the secondary metabolites present in the different morphological parts of $D$. guineense could be due to diverse factors relating to the environment, time of the day and season of collection. In addition, this could also be responsible for the different biological activities reported in the morphological parts of Dialium guineense. 
In this study, the egg albumin induced assay was used to induce inflammation in the animals. The egg albumin causes inflammation by the release of histamine and serotonin during the second phase of inflammation thereby causing vasodilation and increased permeability.

The leaf extract of $D$. guineense exhibited mild anti-inflammatory effect while, the seed oil of $D$. guineense exerted time -dependent anti-inflammatory activities which was more pronounced than the effect of the standard drug. At a dose of $1 \mathrm{~mL}$ and $0.5 \mathrm{~mL}$ the effect shown were not significantly different from each other over the test period. Figure 1 and 2.

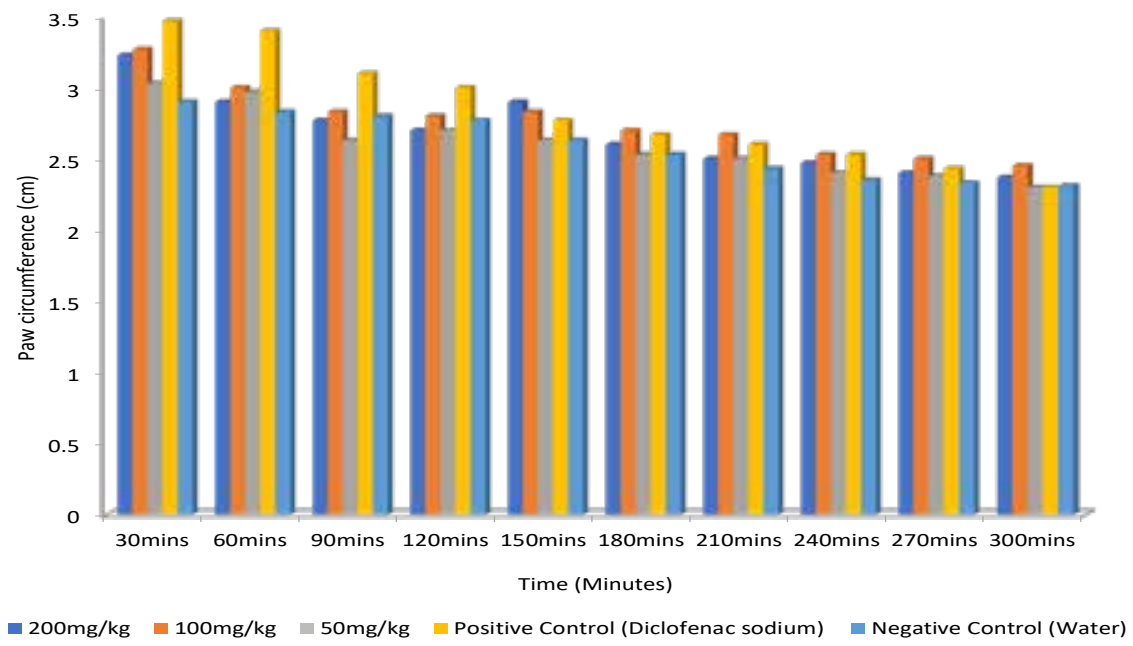

Figure 1: Anti-Inflammatory Effects of Dialium guineense Methanol Leaf Extract.

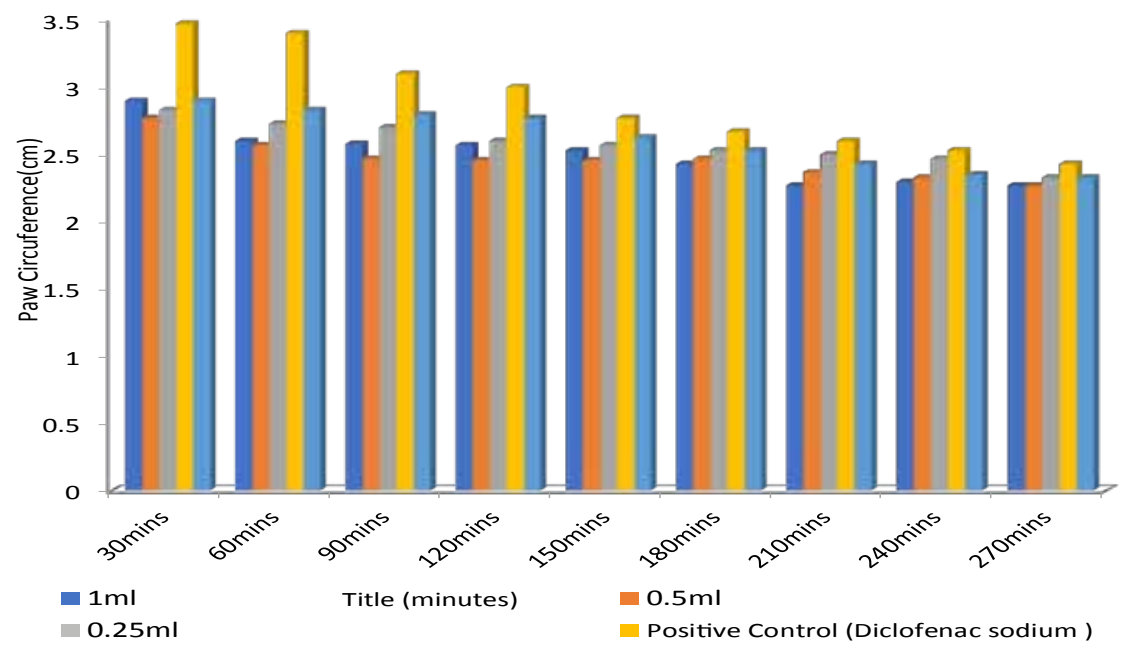

Figure 2: Anti-Inflammatory effects of Dialium guineense Seed Oil. 
The presence of anthraquinones, flavonoids and sterols in the leaf extract and seed oil of $D$. guineense had a culminative effect which helped in wound healing and anti-inflammatory activity in the test animals. Tannins present in high concentration in the leaf could act by detoxifying as well as inhibit microbial growth ${ }^{26}$. The sterols present both in the leaf extract and seed oil have astringent properties while flavonoids have potency in acting as free scavengers as well as prevent prostaglandin synthesis a major factor responsible for the second phase of inflammation.

Furthermore, these phenolic compounds in the leaf and seed oil of D. guineense are also able to exert wound healing and anti-inflammatory effect by synergy thereby aiding cell migration, the proliferation of cells, fibroblasts, keratocytes, tissue repairs, thereby promoting blood vessel contraction, collage deposit, modulating the production of reactive oxidative stress, chelating free radicals as well as inhibiting the production of nitric oxide at wound site.

In previous study, the wound healing effect of the Dichloromethane fraction of the fruit coat of Dialium guineense have been reported ${ }^{28}$. This study further confirms and shows the ability of the phytoconstitutents in D. guineense to heal wounds as well as reduce inflammation through possible diverse mechanism of actions. One of which is possible by suppressing or inhibiting the release of histamine, serotonin and prostalglandin. This study therefore has been able to justify the use of Dialium guineense in folklore medicine as an agent of wound healing.

\section{STATEMENT OF ETHICS}

Approval was obtained from the Animal Ethical Committee (OOU/PCG/ AEC/2020001) and animals were handled according to the National Institutes of Health guide for the care and use of Laboratory Animals

\section{CONFLICT OF INTEREST}

The Authors declare that there is no Conflict of Interest.

The Authors declare they have no competing Interests.

\section{FUNDING SOURCE}

This study did not receive financial support towards this study.

\section{AUTHORS CONTRIBUTION}

Adediwura Fred-Jaiyesimi conceived the study, concept, and design, Oluwakemi Ogunleye and Mary Adesina conducted most of the Laboratory experiments, Peter Segun, Modupe Adebowale and Katherine Olufolabo contributed to the proposal. Adediwura Fred-Jaiyesimi and Modupe Adebowale contributed to the supervision of the study. All authors read and approved the final manuscript. 


\section{REFERENCES}

1. Besong EE, Balogun ME, Djobissie SFA, Obu DC, Obimma JN. Medicinal and Economic value of Dialium guineense. Afr J Biomed Res. 2016; 19: 163 - 170.

2. Nwosu MO. Plant resources used by traditional woman as herbal cosmetics in South West Nigeria. Arzte fur natur Fahr. 20oo; 41: 760 - 767.

3. Akinpelu, AD, Awoterebo TO, Agunbiade OM, Aiyegoro AO, Okoh IA. Antivibrio and preliminary phytochemical characteristics of crude methanolic extract of the leaves of Dialum guineense (Wild). J Med Plt Res. 2011; 511: 2398 - 2404.

4. Hutchinson J, Dalziel MJ. Flora of West Tropical Africa. 2nd edition. Milbank, London: Crown Agents for Overseas Governments and Administration. Millbank; 1958. 567-569 p.

5. Keay RWJ. Trees of Nigeria. London: Oxford Clarendon Press; 1989, pp476.

6. Arogba SS, Ajiboro A, Odukwe I. A physico-chemical study of Nigeria velvet tamarind (Dialium guineense L) fruit. J Sci Food and Agric. 2oo6; 66: 533 - 534.

7. Bero J, Ganfen H, Jo ville MC, Frederich M, Gbaguidi F, De MP. In vitro antiplasmodial activity of plants used in traditional medicine to treat malaria. $J$ Ethnopharmacol. 2oog; 122: $439-444$.

8. Odukoya OA, Houghton PJ, Adelusi A, Omogbai EKI, Sanderson L, Whitfield PJ. Molluscicidal triterpenoid glycosides of Dialium guineense. J Nat Prod. 1996; 59: 632 - 634 .

9. Oyegoke RA, Oladiji AT. Antiulcerogenic Activity of Dialium guineense Fruit pulp mealbased diet in Aspirin-induced ulcerogenic rats. Nig J Biochem Mol Bio. 2014; 29: 77 - 93.

10. Ezeja MI, Omeh YS, Ezeigbo A, Ikechukwu A. Evaluation of the analgesic activity of the methanolic extract of Dialium guineense (Wild). Ann Med Health Sci Res. 2011; 1: 55 - 62

11. Orji JO, Alo MN, Anyim C, Okonkwo EC. Antibacterial activities of crude leaf and bark extracts of "icheku" Dialium guineense on bacterial isolates from bronchitis patients. IOSR J Pharm Biol Sci. 2012; 1: 21 - 25.

12. Balogun ME, Oji JO, Besong EE, Umahi GO. Evaluation of the anti-ulcer properties of aqueous leaf extract of Dialium guineense (Velvet tamarind) on experimentally induced ulcer models rats. Int J Dev Res. 2013; 3: 106-110.

13. David AA, Olaniyi AT, Mayowa AO, Olayinka AA, Okoh IA. Anti-vibrio and preliminary phytochemical characteristics of crude methanolic extracts of the leaves of Dialium guineense (Wild). J Med Plants Rev. 2011; 5: 2398 - 2404.

14. Ogu GI, Amiebenomo AR. Phytochemical analysis and in vivo antidiarrheal potential of Dialium guineense (Wild) stem bark extract. J Intercult Ethnopharmacol. 2012; 1: 105 - 110.

15. Ajiboye AE, Ameen MT, Adedayo MR. Antimicrobial activity and phytochemical screening of the fruit pulp of Dialium guineense (Velvet Tamarind) on some microbial isolates. J Microbiol Antimicrob. 2015; 7: $33-41$.

16. Harborne JA. Phytochemical Methods A guide to modern Techniques of plant Analysis. 3rd ed. London: Chapman and Hall; 1998. 15-36.

17. Evans WC. Trease and Evans' Pharmacognosy. 15th ed. London: J and A Churchill Ltd; 1996. 234-492 p.

18. Sindhu RK, Sood N, Puri V, Arora S. Various Animal Models for Preclinical Testing of Antiinflammatory Agents. Inter J Pharm Sci Res. 2017, 8: 1550 - 1557.

19. Kumar N, Gupta AK. Wound-healing activity of Onosma hispidum (Ratanjot) in normal 
and diabetic rats. J Herbs Spices Med Plt. 2010; 15: 342-351.

20. Demilew W, Adinew GM, Asrade S. Evaluation of the wound healing activity of the crude extract of leaves of Acanthus polystachyus Delile (Aanthanceae). Evidence Based Complementary and Alternative Medicine. 2018; 9.

21. Kokane DD, More RY, Kale MB, Nehese MN, Mehendale PC, Gadgoli G. Evaluation of wound healing activity of root of Mimosa Pudica J Ethnopharmacol. 2oo9; 124: 311 - 315.

22. British Pharmacopoeia (BP). Department of health and social security Scottish home and health Department office of the British Pharmacopoeia Commission, UK. 1988; 2: 713.

23. Ansel H, Popovich N. Preparation of Topical Dosage forms. Introduction to Pharmaceuical Dosage forms. $4^{\text {th }}$ edition. Philadelphia, USA: Lea \& Febiger; 1985.

24. Yadav E, Singh D, Yadav P, Verma A. Antioxidant and anti-inflammatory properties of Prosporis cineria based phenolic rich ointment in wound healing. Biomed Pharmacother. 2018; 108: 1572 - 1583 .

25. Yadav E, Singh D, Yadav P, Verma A. Ameliorative effect of biofabricated ZnO nanoparticles of Trianthema portulacastrum Linn. on dermal wounds via removal of oxidative stress and inflammation. RSC Adv. 2018; 8: 21621 - 21635.

26. Kipngeno CD, Mshimba SM, Gilbert C. Antimicrobial activity and phytochemical investigation of crude extracts of the fruits of Solanum incarnum (Solanaceae) and Dovgalis abbysimica (Flacourtiaceae). Sci J Microbiol. 2014; 1 - 4 .

27. Agra LC, Ferro JNS, Barbosa FT, Barreto E. Triterpenes with healing activity. A systematic Review. J Dermatol Treat. 2015; 26: 465 - 470.

28. Premarathnaa AD, Ranahewaa TH, Wijesekerab SK, Wijesundaraa RRMKK, Jayasooriyac AP, Wijewardanaa V, et al. Wound healing properties of aqueous extracts of Sargassum illicifolium: An in vitro assay. Wound Med. 2019; 24: 1-7

29. Okeke NC, Udeani TKC, Onyebuchi UL. Wound - healing and Antimicrobial properties of dichloromethane fraction of Dialium guineense (Wild) fruit coat. Res Pharm Sci. 2o16; 11: $219-226$

30. Olajubu FA, Akpan I, Ojo DA, Oluwalana SA. Antimicrobial potential of Dialium guineense (Wild) stem bark on some clinical isolates in Nigeria. Int J Appl Basic Med Res. 2012; 2: 58 -62 . 